\title{
Taxonomy of Penicillium citrinum and related species
}

\author{
Jos A. M. P. Houbraken • Jens C. Frisvad • \\ Robert A. Samson
}

Received: 5 July 2010 /Accepted: 7 July 2010 / Published online: 13 August 2010

(C) The Author(s) 2010. This article is published with open access at Springerlink.com

\begin{abstract}
Penicillium citrinum and related species have been examined using a combination of partial $\beta$-tubulin, calmodulin and ITS sequence data, extrolite patterns and phenotypic characters. It is concluded that seven species belong to the series Citrina. Penicillium sizovae and Penicillium steckii are related to P. citrinum, P. gorlenkoanum is revived, Penicillium hetheringtonii sp. nov. and Penicillium tropicoides sp. nov. are described here as new species, and the combination Penicillium tropicum is proposed. Penicillium hetheringtonii is closely related to $P$. citrinum and differs in having slightly broader stipes, metulae in verticils of four or more and the production of an uncharacterized metabolite, tentatively named PR1-x. Penicillium tropicoides resembles $P$. tropicum, but differs in the slow maturation of the cleistothecia, slower growth at $30^{\circ} \mathrm{C}$ and the production of isochromantoxins. The type strain of $P$. hetheringtonii is CBS $122392^{\mathrm{T}}\left(=\mathrm{IBT} 29057^{\mathrm{T}}\right.$ ) and the type strain of $P$. tropicoides is CBS $122410^{\mathrm{T}}$ $\left(=\right.$ IBT $\left.29043^{\mathrm{T}}\right)$.
\end{abstract}

Keywords Penicillium · Citrinin · Steckii · Sizovae . Citrinum · Taxonomy· Series Citrina

J. A. M. P. Houbraken $(\bowtie) \cdot$ R. A. Samson

Applied and Industrial Mycology,

CBS-KNAW Fungal Biodiversity Centre,

Uppsalalaan 8,

NL-3584 CT Utrecht, the Netherlands

e-mail: j.houbraken@cbs.knaw.nl

J. C. Frisvad

Department of Systems Biology,

Technical University of Denmark,

Building 221, Søltofts Plads,

DK-2800 Kgs. Lyngby, Denmark

\section{Introduction}

Penicillium citrinum is a commonly occurring filamentous fungus with a worldwide distribution and it may well be one of the most commonly occurring eukaryotic life forms on earth (Pitt 1979). This species has been isolated from various substrates such as soil, (tropical) cereals, spices and indoor environments (Samson et al. 2004). Citrinin, a nephrotoxin mycotoxin named after P. citrinum (Hetherington and Raistrick 1931), is consistently produced by $P$. citrinum. In addition, several other extrolites, such as tanzowaic acid A, quinolactacins, quinocitrinines, asteric acid and compactin are reported to be produced by this species (Kim et al. 2001; Kozlovskiĭ et al. 2003a, b, Malmstrøm et al. 2000; Turner and Aldridge 1983).

Raper and Thom (1949) placed P. citrinum in section Asymmetrica, subsection Velutina and introduced the "Penicillium citrinum series" for P. steckii, P. corylophilum and P. citrinum. Ramirez (1982) followed Raper and Thom's concept, and added P. matritii to this series. A classification system based on the branching pattern of the penicillus was introduced by Pitt (1979), and P. citrinum was placed in the subgenus Furcatum, section Furcatum, series Citrina. In this monograph, P. citrinum was used to typify the subgenus Furcatum and the series Citrina. Seven species were placed in the series Citrina, and members of this series share similar growth rates and have terminal verticils of metulae with small conidia. Several species were placed in synonymy with $P$. citrinum, namely $P$. baradicum, $P$. gorlenkoanum, $P$. botryosum, $P$ sartoryi, $P$. steckii, P. aurifluum, P. subtile and Citromyces subtilis. Peterson (2000) made a phylogenetic analysis of various Penicillium species belonging to the subgenera Aspergillioides, Furcatum and Penicillium. Based on his data, it was shown that $P$. sartoryi is distinct from $P$. citrinum and 
should be revived. Furthermore, P. matritii and P. corylophilum, previously claimed to be related to $P$. citrinum (Raper and Thom 1949; Pitt 1979; Ramirez 1982), were positioned in phylogenetic distant clades.

In this study, $P$. citrinum and related species are examined using the ITS regions (intergenic spacer region and 5.8S rDNA gene) and parts of the $\beta$-tubulin and calmodulin gene, in combination with extrolite profiles, physiology and macro- and microscopical characters. A large set of isolates, including the type strains of various synonyms and freshly isolated strains are included in this study.

\section{Material and methods}

Isolates

The examined strains included type strains or representatives of species related to P. citrinum. Additional strains were isolated from various substrates, such as soils from different locations, food- and feedstuffs and air. An overview of strains used in this study is presented in Table 1. All strains are maintained in the CBS culture collection.

DNA isolation, amplification and analysis

The strains were grown on Malt Extract agar (MEA, Oxoid) for $4-7$ days at $25^{\circ} \mathrm{C}$. Genomic DNA was isolated using the Ultraclean ${ }^{\mathrm{TM}}$ Microbial DNA Isolation Kit (MoBio, Solana Beach, U.S.A.) according the manufacturer's instructions. Fragments, containing the ITS regions, a part of the $\beta$-tubulin or calmodulin gene, were amplified and subsequently sequenced according the procedure previously described (Houbraken et al. 2007). The alignments and analyses were preformed as described by Samson et al. (2009), with one modification: to prevent saturation of the computer's memory, the maximum number of saved trees for the ITS dataset was set to 5,000. Penicillium corylophilum CBS 330.79 , was used as an outgroup in all analyses. Additional sequences of $P$. sumatrense, $P$. manginii, $P$. decaturense, $P$. chrzaszcii, $P$. waksmanii, $P$. westlingii, $P$. miczynskii, $P$. paxilli, $P$. roseopurpureum, Penicillium shearii and $P$. anatolicum were added to the ITS dataset to determine the phylogenetic relation with $P$. citrinum. The newly derived sequences used in this study were deposited in GenBank under accession numbers GU944519-GU944644, the alignments in TreeBASE (www.treebase.org/treebase-web/home.html), and taxonomic novelties in MycoBank (www.MycoBank.org; Crous et al. 2004).
Morphology and physiology

The strains were inoculated in a three point position on Czapek yeast autolysate agar (CYA), malt extract Agar (MEA), creatine agar (CREA) and yeast extract sucrose agar (YES). Growth characteristics were measured and determined after an incubation period of 7 days at $25^{\circ} \mathrm{C}$ in darkness. Light microscopes (Olympus $\mathrm{BH} 2$ and Zeiss Axiokop two Plus) were used for microscopic examination and a set 25 micromorphological dimensions was obtained for each characteristic. Ripening of the cleistothecia was checked for up to 3 months. Colours of cleistothecia were determined on Oatmeal agar (OAT) after seven and 14 days of incubation at $25^{\circ} \mathrm{C}$. Temperature-growth data was studied on CYA plates, which were inoculated in a threepoint position and incubated at $12^{\circ} \mathrm{C}, 15^{\circ} \mathrm{C}, 18^{\circ} \mathrm{C}, 21^{\circ} \mathrm{C}$, $24^{\circ} \mathrm{C}, 27^{\circ} \mathrm{C}, 30^{\circ} \mathrm{C}, 36^{\circ} \mathrm{C}, 37^{\circ} \mathrm{C}$ and $40^{\circ} \mathrm{C}$. The colony diameters were recorded after 7 days of incubation in darkness.

\section{Extrolites}

Culture extracts were made from the agar media CYA and YES according the method described by Smedsgaard (1997). The extracts were analysed by HPLC with diode array detection according the method described by Frisvad and Thrane $(1987,1993)$. The extrolites were identified by their retention times and UV spectra. Authentic analytical standards were employed for retention time and retention index comparison with the extrolites detected.

\section{Results}

Phylogenetic analysis

The ITS regions and parts of the $\beta$-tubulin and calmodulin gene were sequenced and analysed. The trees obtained from the maximum parsimony analysis are shown in Figs. 1, 2, 3. Molecular data revealed that six species are related to $P$. citrinum. Four of these species are strictly anamorphic, $P$. hetheringtonii, P. sizovae, P. steckii and P. gorlenkoanum, and two form a teleomorph, namely $P$. tropicum and $P$. tropicoides.

The ITS regions included $520 \mathrm{bp}$, of which $10 \%$ were parsimony-informative. The heuristic search generated more than 5,000 equally parsimonious trees, which were 129 steps long. Phylogenetic analysis of the ITS dataset resulted in low bootstrap supports of the clades and only the connection between $P$. citrinum and $P$. hetheringtonii was highly supported $(100 \%)$. Both $P$. sumatrense and $P$. gorlenkoanum were basal to $P$. citrinum and related species. However, this is not supported by the $\beta$-tubulin and 
Table 1 Details of isolates included in the morphological and/or molecular examination of this study

\begin{tabular}{|c|c|c|}
\hline Species & CBS number & Substrate and locality \\
\hline P. citrinum & 139.45 & Ex type of $P$. citrinum and $P$. aurifluum, unrecorded source \\
\hline P. citrinum & 252.55 & Ex-type of P.botryosum, herbarium specimen, Recife, Brazil \\
\hline P. citrinum & 241.85 & IMI 092267; ex type of $P$. phaeojanthinellum, unrecorded source \\
\hline P. citrinum & 122726 & NRRL 783; representative of $P$. sartoryi, unrecorded source \\
\hline P. citrinum & 115992 & Compost, the Netherlands \\
\hline P. citrinum & 122398 & Peanut, Indonesia \\
\hline P. citrinum & 122397 & Soil, Treasure Island, Florida, USA \\
\hline P. citrinum & 865.97 & Patient with acute myeloid leukemia, Hong Kong, China \\
\hline P. citrinum & 122395 & Coconut milk; produced in Indonesia, imported into the Netherlands \\
\hline P. citrinum & 122394 & Soil, Merang, Malaysia \\
\hline P. citrinum & 232.38 & $\begin{array}{l}\text { Type of } P \text {. implicatum; original culture deposited by Thom (as Thom } \\
\text { 4733.73), unknown source, Belgium }\end{array}$ \\
\hline P. citrinum & 117.64 & Epoxy softener, the Netherlands \\
\hline P. citrinum & 122452 & Coffee beans, Thailand; colour mutant \\
\hline P. citrinum & 122451 & NRRL 2145; colour mutant; unrecorded source \\
\hline P. citrinum & 101275 & Leaf, Panama \\
\hline P. gorlenkoanum & 408.69 & Ex-type strain of $P$. gorlenkoanum; soil, Syria \\
\hline P. gorlenkoanum & 411.69 & Ex-type strain of $P$. damascenum; soil, Syria \\
\hline P. hetheringtonii & 122392 & Type; soil, Treasure Island, Florida, USA \\
\hline P. hetheringtonii & 124286 & Soil, Lookout Kuranda, Queensland, Australia \\
\hline P. hetheringtonii & DTO $30 \mathrm{H} 7$ & Soil, Lookout Kuranda, Queensland, Australia \\
\hline P. hetheringtonii & 124287 & Soil, Lake Easchem, Queensland, Australia \\
\hline P. sizovae & 413.69 & Neotype of $P$. sizovae; soil, Syria \\
\hline P. sizovae & 122387 & Margarine, the Netherlands \\
\hline P. sizovae & 139.65 & Sea salt, Portugal \\
\hline P. sizovae & 122386 & Glue, the Netherlands \\
\hline P. sizovae & 115968 & Cropped soil, Italy \\
\hline P. sizovae & 117183 & Papaver somniferum, the Netherlands \\
\hline P. sizovae & 117184 & IBT 22812; salty water in saltern, Slovenia \\
\hline P. steckii & 325.59 & Ex-type of $P$. corylophiloides nom. inval.; ex soil Japan \\
\hline P. steckii & 789.70 & Unrecorded source \\
\hline P. steckii & 122391 & Potting soil, the Netherlands \\
\hline P. steckii & 260.55 & Ex-neotype of $P$. steckii; cotton fabric treated with copper naphthenate, Panama \\
\hline P. steckii & 122390 & $\begin{array}{l}\text { IBT 21096; Caranx crysos (blue runner, fish), sand bottoms with } \\
\text { corals, surface water } 23^{\circ} \mathrm{C} \text {, dept } 2-3 \mathrm{~m} \text { at Cabruta, Mochima Bay, Venezuela }\end{array}$ \\
\hline P. steckii & 122389 & IBT 19353 = IFO 6024; unrecorded source \\
\hline P. steckii & 122388 & IBT 14691 = NRRL 6336; baled coastal grass hay, Bermuda \\
\hline P. steckii & 122418 & IBT 6452; Cynara scolymus (Artichoke), Egypt \\
\hline P. steckii & 122417 & $\begin{array}{l}\text { IBT 20952; Ascidie (tunicate, urochordata), sand bottoms with corals, } \\
\text { surface water } 23^{\circ} \mathrm{C} \text {, dept } 2-3 \mathrm{~m} \text { at Cabruta, Mochima Bay, Venezuela }\end{array}$ \\
\hline P. tropicoides & 122410 & Type; soil of rainforest, near Hua-Hin, Thailand \\
\hline P. tropicoides & 122436 & Soil of rainforest, near Hua-Hin, Thailand \\
\hline P. tropicum & 112584 & Ex-type; soil between Coffea arabica, Karnataka, India \\
\hline
\end{tabular}

calmodulin datasets. Penicillium gorlenkoanum appeared to be related to $P$. citrinum in these datasets, and $P$. sumatrense formed a clade unrelated to $P$. citrinum, $P$. westlingii, $P$. paxilli, $P$. roseopurpureum or $P$. shearii (data not shown). A gap of 36-38 bp was observed in the ITS1 region of all $P$. citrinum and $P$. hetheringtonii isolates. However, analysis of other Penicillium strains showed that this feature is not species specific, since one isolate of $P$. manginii (CBS 327.79) also has this deletion, while another has not (CBS $\left.253.31^{\mathrm{T}}\right)$. The ITS dataset showed less resolution than the 


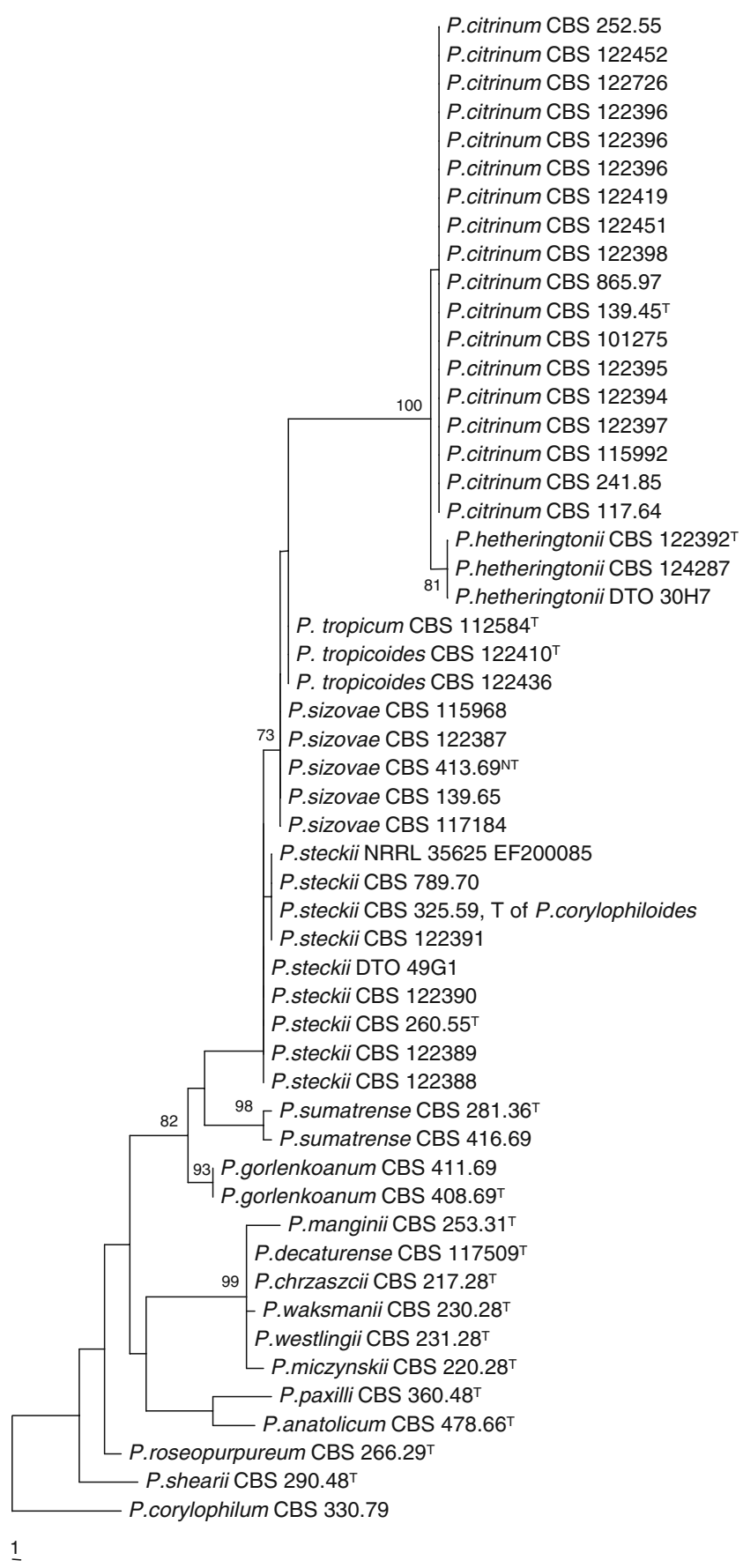

Fig. 1 One of the 128 equally most parsimonious trees of the analysed ITS region (55 of the 629 characters were parsimony informative; tree length $=95, \mathrm{CI}=0.652, \mathrm{RI}=0.948, \mathrm{RC}=0.653$ )

$\beta$-tubulin and calmodulin datasets, and P. tropicum and $P$. tropicoides had no differences in their ITS regions. The other five species could be differentiated based on their ITS sequence, and a subgroup in the $P$. steckii clade was observed. This subgroup, characterized by a single basepair difference on position 164 of the ITS2 region, included the type strain of $P$. corylophiloides nom. inval. (CBS 325.59).
The $\beta$-tubulin and calmodulin datasets were more variable than the ITS dataset. The $\beta$-tubulin dataset consisted of $473 \mathrm{bp}$, of which $15 \%$ was parsimony informative. The heuristic search yielded two equally parsimonious trees of 166 steps. 456 characters of the calmodulin dataset were analysed and $20 \%$ was parsimony informative. The analysis generated six equally most parsimonious trees of 171 steps long. Both phylograms only had high bootstrap support at the nodes. The basal nodes were different between the two datasets and they were in both cases not supported by high bootstrap values. Penicillium steckii was split, similar to the ITS dataset, into two groups with high bootstrap support. The grouping of the isolates was in all cases identical, suggesting absence of recombination between these clades. The calmodulin and ITS phylograms show a high bootstrap support $(84 \%$ and $100 \%$ respectively) between $P$. hetheringtonii and $P$. citrinum. Also a high bootstrap support (89\%) is present in the $\beta$-tubulin dataset between P. sizovae on the one hand and $P$. tropicum and P. tropicoides on the other.

Morphology and physiology

Various phenotypic differences were observed among the investigated species (see Table 2). Growth rates on CYA incubated at 30 and $37^{\circ} \mathrm{C}$, and reverse colours and growth rates on CYA and YES at $25^{\circ} \mathrm{C}$ were useful characters for differentiation between $P$. citrinum and related species (Fig. 4). The examined P. citrinum strains consistently grew at $37^{\circ} \mathrm{C}$. Some strains of P. sizovae (five of seven) and $P$. hetheringtonii (one of four) were able to grow at this temperature, though more restricted than P. citrinum. All species were able to grow at $30^{\circ} \mathrm{C}$, though with different growth rates. This feature was also useful to differentiate between the members of the series Citrina and other related species such as $P$. westlingii, P. waksmanii, P. miczynskii and $P$. manginii, which were not able to grow at this temperature (data not shown). The reverse colours on YES varied from (pale) crème in P. sizovae and P. steckii to shades of orange in $P$. citrinum and $P$. hetheringtonii. The reverse colours on CYA were less pronounced and varied from pale to brownish yellow. Creatin agar, which is used for identification of species belonging to subgenus Penicillium (Frisvad 1985; Samson and Frisvad 2004) was also tested, but had little discriminatory power. Most species showed weak growth with no or weak acid production. The only exception was $P$. steckii, which grew weak to moderate on this medium.

Comparison of the micro-morphology showed differences in branching of the conidiophores, and shape and ornamentation of the conidia. All the species have smooth stipes, small conidia $(2-3 \mu \mathrm{m})$ and share symmetric biverticillate conidiophores with occasionally an additional branch. Additional branching was most often seen in 
Fig. 2 One of the two equally most parsimonious trees of the analysed BenA region (71 of the 473 characters were parsimony informative; tree length $=166$, $\mathrm{CI}=0.898, \mathrm{RI}=0.964$, $\mathrm{RC}=0.865$ )

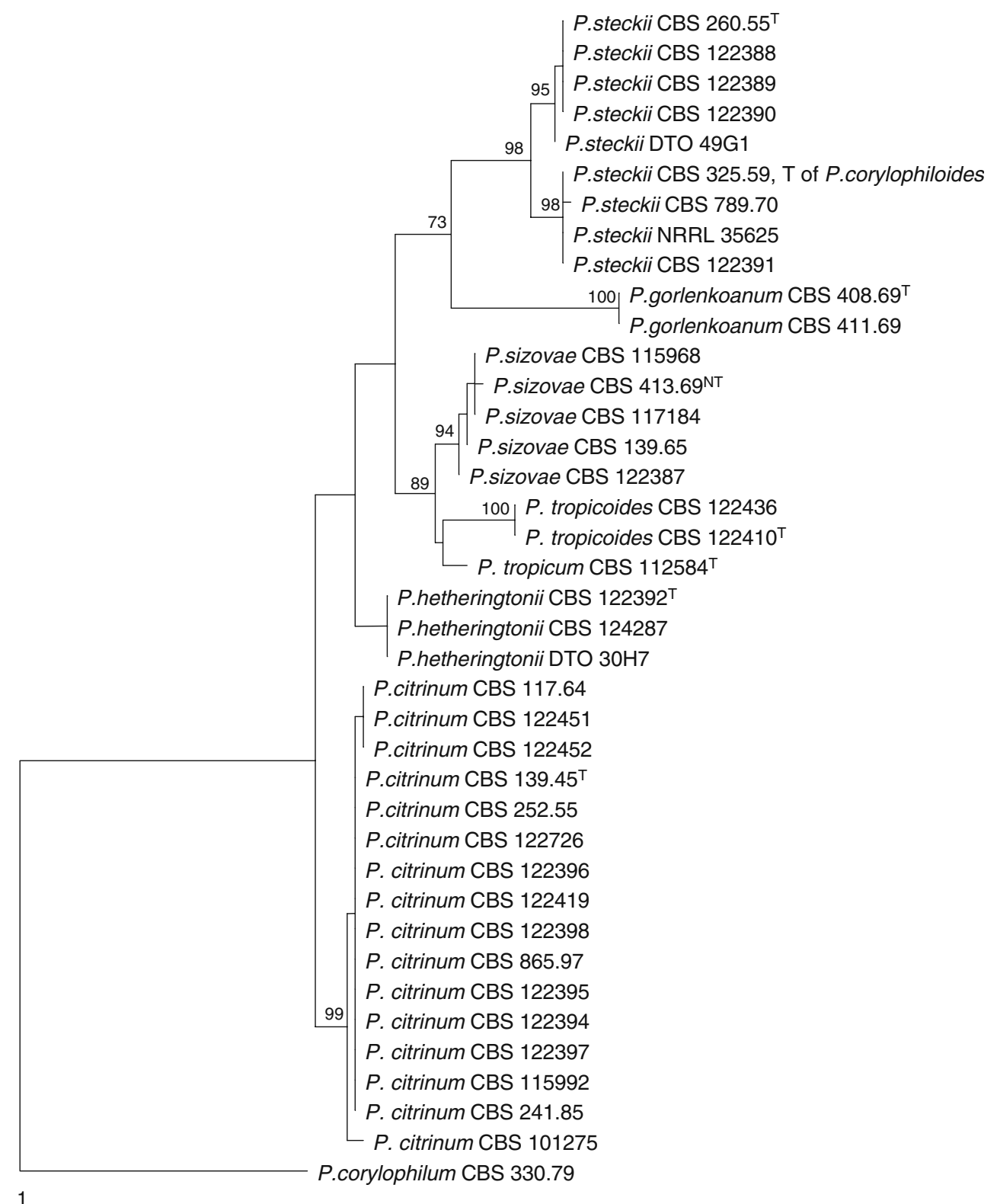

freshly isolated strains of $P$. citrinum and $P$. hetheringtonii and not or less in the other species. Most species had globose, smooth walled conidia. Exceptions were P. steckii, $P$. tropicum and P. tropicoides, which have (broadly) ellipsoidal conidia and $P$. sizovae, which has finely roughened conidia.

\section{Extrolites}

The mycotoxins and other extrolites produced by the examined species are listed in Table 3. Several extrolites, such as citrinin, quinolactacin, isochromantoxins and an unknown metabolite named PR1-x, were produced by more than one species. The examined species could be differentiated based on their characteristic pattern of extrolites.
Taxonomy

Penicillium citrinum Thom, Bulletin of the U.S. Department of Agriculture, Bureau Animal Industry 118: 61. 1910.

= Citromyces subtilis Bainier \& Sartory, Saccardo's Syll. fung. XXV: 684. 1912.

$=$ Penicillium subtile (Bainier \& Sartory) Biourge, Cellule 33: 106, 1923 (nom. Illegit.,Art. 64; non Berk. 1841.

= Penicillium aurifluum Biourge, Cellule 33: 250. 1923.

= Penicillium phaeojanthinellum Biourge, Cellule 33: 289. 1923.

= Penicillium implicatum Biourge, La Cellule 33(1): 278. 1923. 
Fig. 3 One of the six equally most parsimonious trees of the analysed $\mathrm{Cmd}$ region (89 of the 456 characters were parsimony informative; tree length $=171$, $\mathrm{CI}=0.872, \mathrm{RI}=0.959$, $\mathrm{RC}=0.836$ )

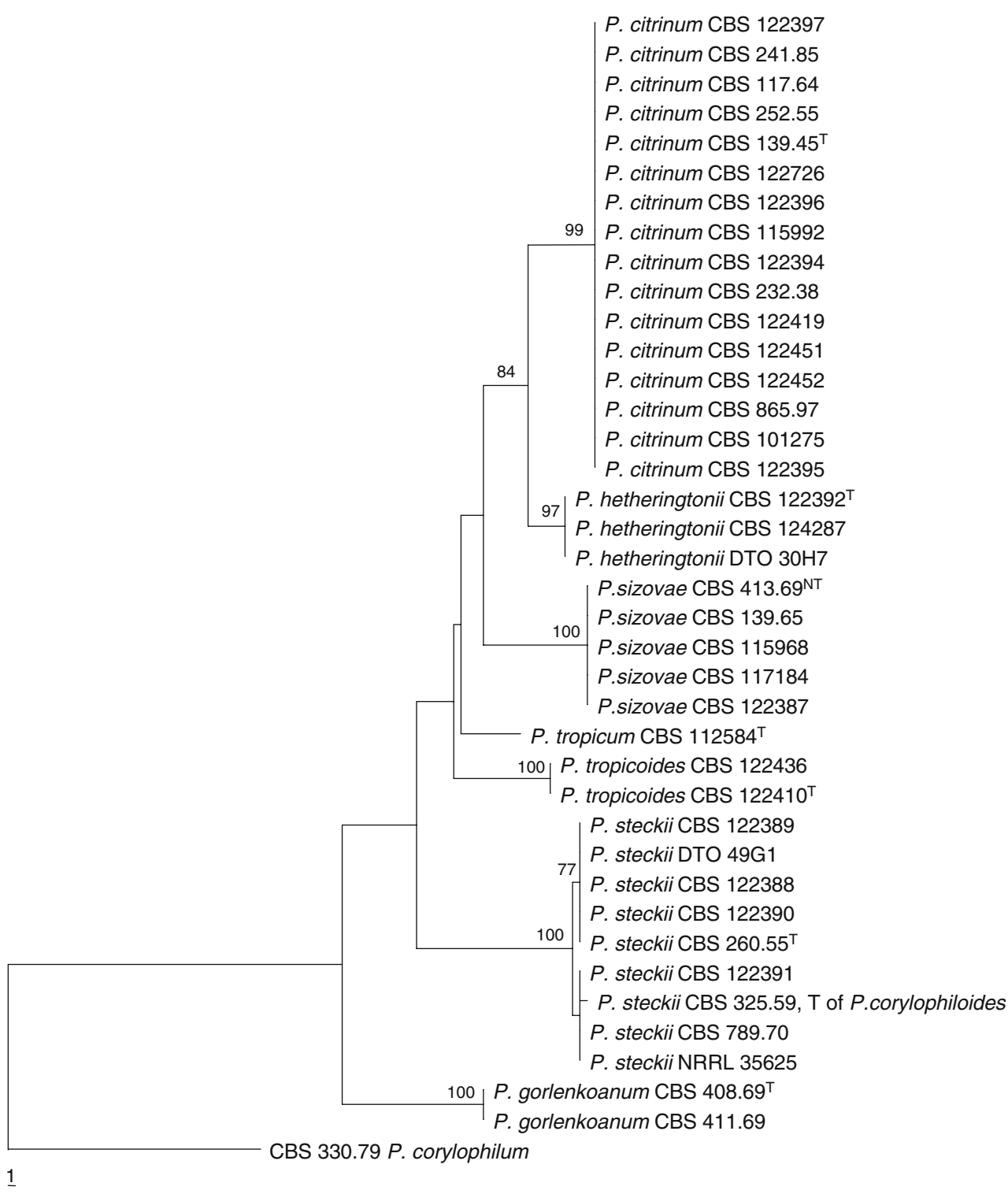

Table 2 Overview of morphological and physiological characters to differentiate between $P$. citrinum and related species

\begin{tabular}{|c|c|c|c|c|c|c|c|}
\hline Species & $\begin{array}{l}\text { Colour conidia } \\
\text { on MEA }\end{array}$ & $\begin{array}{l}\text { Reverse colour } \\
\text { on CYA }\end{array}$ & $\begin{array}{l}\text { Reverse colour } \\
\text { on YES }\end{array}$ & $\begin{array}{l}\mathrm{CYA} \\
30^{\circ} \mathrm{C}(\mathrm{mm})\end{array}$ & $\begin{array}{l}\mathrm{CYA} \\
37^{\circ} \mathrm{C}(\mathrm{mm})\end{array}$ & $\begin{array}{l}\text { Shape and ornamentation } \\
\text { conidia }\end{array}$ & $\begin{array}{l}\text { Presence of } \\
\text { cleistothecia }\end{array}$ \\
\hline P. citrinum & Blue grey green & Brownish yellow & $\begin{array}{l}\text { Yellow or } \\
\text { orange-yellow }\end{array}$ & $30-36(-43)$ & $2-11$ & $\begin{array}{l}\text { Globose to subglobose, } \\
\text { smooth }\end{array}$ & Absent \\
\hline P. gorlenkoanum & Grey green & Crème-brown & Pale yellow & $(20-) 25-30$ & No growth & $\begin{array}{l}\text { Globose to subglobose, } \\
\text { smooth }\end{array}$ & Absent \\
\hline P. hetheringtonii & Dark blue green & Brownish yellow & Orange & $29-35$ & $0-5$ & $\begin{array}{l}\text { Globose to subglobose, } \\
\text { smooth }\end{array}$ & Absent \\
\hline P. sizovae & Grey green & Pale & $\begin{array}{l}\text { Yellowish crème } \\
\text { to crème }\end{array}$ & $30-35$ & $0-5$ & $\begin{array}{l}\text { Globose to subglobose, } \\
\text { finely roughened }\end{array}$ & Absent \\
\hline P. steckii & Grey or dull green & Crème-brown & $\begin{array}{l}\text { Yellowish crème } \\
\text { to crème }\end{array}$ & $15-20(-25)$ & No growth & $\begin{array}{l}\text { Broadly ellipsoidal, in } \\
\text { some strains slightly } \\
\text { fusiform, smooth }\end{array}$ & Absent \\
\hline P. tropicoides & $\begin{array}{l}\text { Conidia sparely } \\
\text { produced; blue } \\
\text { grey green }\end{array}$ & Brown & Yellow & $15-25$ & No growth & $\begin{array}{l}\text { Broadly ellipsoidal, } \\
\text { smooth }\end{array}$ & Present \\
\hline P. tropicum & $\begin{array}{l}\text { Conidia sparely } \\
\text { produced; blue } \\
\text { grey green }\end{array}$ & Brown & Crème yellow & $25-30$ & No growth & $\begin{array}{l}\text { Broadly ellipsoidal, } \\
\text { smooth }\end{array}$ & Present \\
\hline
\end{tabular}




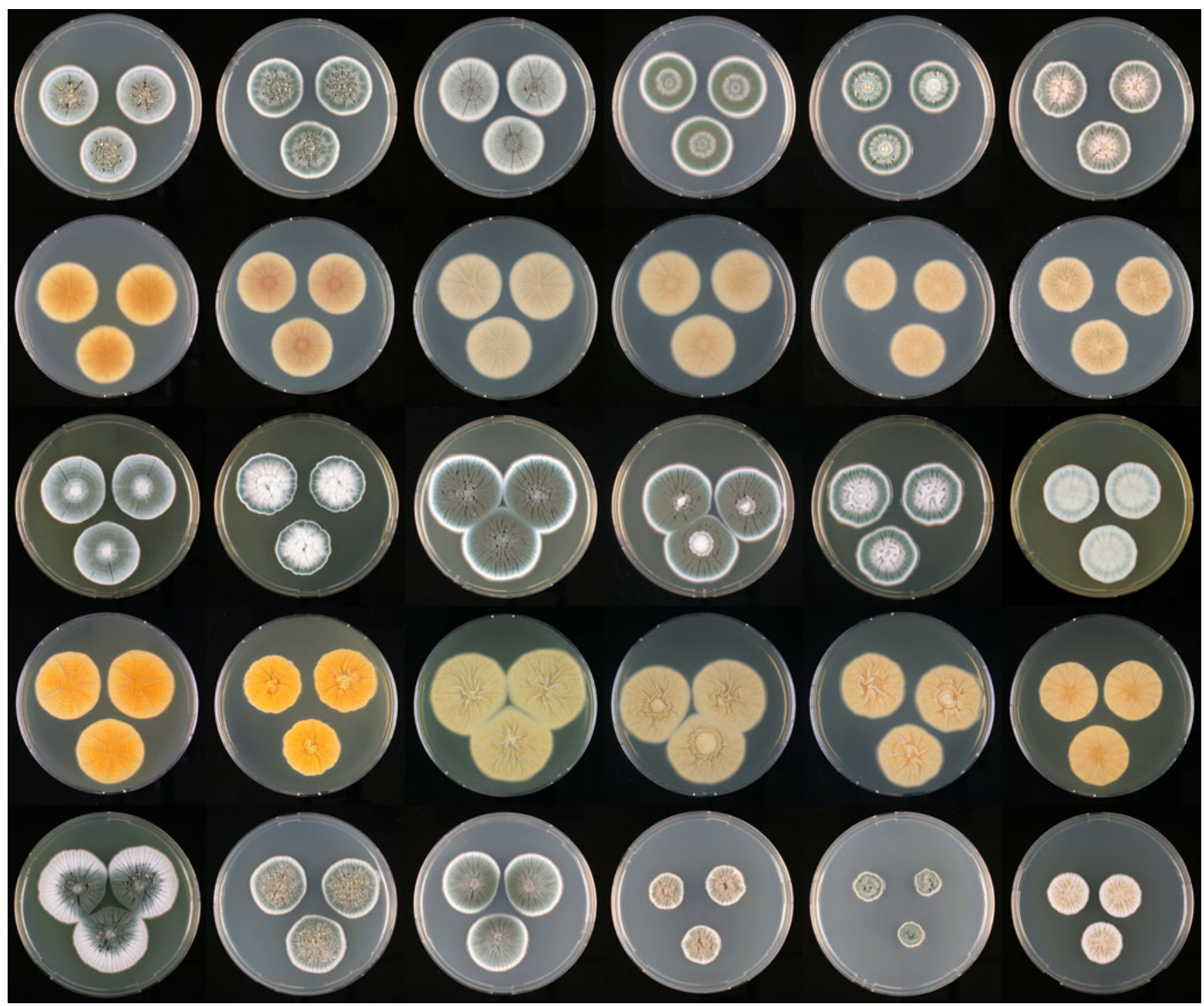

Fig. 4 Overview of $P$. citrinum and related anamorphic species on various agar media. Rows: CYA obverse, CYA reverse, YES obverse, YES reverse and CYA incubated $30^{\circ} \mathrm{C}$. Columns, from left to right: $P$. citrinum $\mathrm{CBS}$ 232.38, P. hetheringtonii CBS 124287, P. sizovae CBS 122387, P. steckii CBS 122388, P. steckii ("P. corylophiloides") CBS 122391 and $P$. gorlenkoanum CBS 408.69
$=$ Penicillium sartoryi Thom [as 'sartorii'], The Penicillia: 233. 1930.

= Penicillium botryosum Bat. \& H. Maia, Anais Soc. Biol. Pernambuco 15(1): 157. 1957.

Type: IMI $92196 \mathrm{ii}^{\mathrm{NT}}$ (P. citrinum and P. aurifluum); other ex-type: CBS $139.45=$ Biourge $53=$ Thom $4733.14=$ ATCC $1109=$ ATCC $36382=$ CECT $2269=$ FRR $1841=$ IMI $091961=$ IMI $092196=$ LSHB P25 $=$ LSHB P6 $=$ LSHB Ad95 = MUCL $29781=$ NRRL $1841=$ NRRL 1842.

Description: Colony diameter, 7 days, in mm: CYA $27-$ 33; $\mathrm{CYA} 30^{\circ} \mathrm{C} 27-40$; $\mathrm{CYA} 37^{\circ} \mathrm{C}$ 2-12; MEA 18-25; YES 29-37; CYAS 29-36; creatine agar 10-19, poor growth, no or weak acid production.
Moderate sporulation on CYA with grey green or blueish grey green conidia, occasionally with small clear or pale yellow exudate droplets, reverse brownish-yellow, diffusible pigments yellow. Moderate to good sporulation on YES, conidial color variable: grey green to dark green, reverse yellow to orange yellow and strong yellow soluble pigment production. Colonies on MEA grey green with a strong blue element, velvety, occasionally with small pale yellow exudate droplets. No reaction with Ehrlich test.

Conidiophores arising from mycelium mat, predominant symmetrically biverticillate, terverticillate structures abundantly produced in fresh isolates; stipes smooth, width $2.0-3.0 \mu \mathrm{m}$; metulae in whorls of $3-4(-6)$, $12-16 \times 2.0-2.7 \mu \mathrm{m} ;$ phialides ampulliform, 7.5- 
Table 3 Mycotoxins and other extrolites produced by the examined species

\begin{tabular}{ll}
\hline Species & Extrolites \\
\hline P. citrinum & $\begin{array}{c}\text { Citrinadins, citrinin, quinolactacin, } \\
\text { anthraquinone with emodin chromophore } \\
\text { Chanoclavine-I, citrinin }\end{array}$ \\
$\begin{array}{l}\text { P. gorlenkoanum } \\
\text { Petheringtonii }\end{array}$ & Citrinin, quinolactacin, PR1- ${ }^{\mathrm{a}}$ \\
P. sizovae & Agroclavine-I, epoxyagaroclavine-I and \\
& $1,1-$ bis(6,8-dimethyl-8,9-epoxy-5a,10e)- \\
& ergoline, quinolactacin \\
P. steckii & Isochromantoxins, quinolactacin, \\
& tanzawaic acids E and $\mathrm{F}$ \\
P. tropicoides & Isochromantoxins, PR1- $\mathrm{x}^{\mathrm{a}}$ and apolar \\
& indol alkaloids \\
P. tropicum & Apolar indol alkaloids and other \\
& uncharacterized extrolites
\end{tabular}

${ }^{a}$ PR1-x is an unknown extrolite with a characteristic UV spectrum.

$10 \times 2.0-2.5 \mu \mathrm{m}$; conidia smooth walled, globose to subglobose, $2.0-2.5 \times 1.8-2.5 \mu \mathrm{m}$.

Diagnostic features: Restricted growth on CYA $37^{\circ} \mathrm{C}(2-$ $12 \mathrm{~mm}$ ), yellow reverse on CYA, globose, smooth walled conidia.

Extrolites: Citrinin, quinolactacins, citrinadins, several anthraquinones, the uncharacterized extrolites, tentatively named "CITY" and "shamix".

Distribution and ecology: Worldwide occurrence: predominant in (sub)tropical soils, but also isolated from indoor air, food and as an endophyte of root, stem and leaves of coffee plants (Posada et al. 2007) and roots of Ixeris repens (Khan et al. 2008; identity based on ITS sequences deposited on GenBank).

Notes: Thom (1910) did not designate a type, but a subculture from his original strain was sent, via Kral, to Biourge. Biourge believed that this strain was contaminated and a culture derived from this strain was described as $P$. aurifluum. Later, $P$. aurifluum was sent to Thom and he recognized it as $P$. citrinum and therefore this strain is accepted to be derived from the original isolate (Pitt 1979). Raper and Thom (1949) mentioned that their concept of $P$. citrinum is broad in scope and included forms which vary substantially in particular characteristics. It was noted that $75 \%$ of the strains fully comply with their species description, and for the remaining strains, six groups were introduced. Representatives of the first group are NRRL 1171 and NRRL 2143 and re-identification of these strains proved to be P. citrinum (Malmstrøm et al. 2000). Raper and Thom's group 2 is centered on strains NRRL 2144 and NRRL 1841, and the latter was later used to typify $P$. citrinum. Group 3 contains strains which are transitional towards $P$. chrysogenum and are claimed to produce both citrinin and penicillin. Examination of the representative of this group, NRRL 822, showed to be a P. chrysogenum (as $P$. rubens), and no citrinin was produced by this strain (Samson and Frisvad 2004). The P. citrinum isolates, which resemble typical $P$. citrinum strains in macromorphological characters, but have variously branched or monoverticillate conidiophores, were placed in group 4. NRRL 783 and NRRL 784 are representatives of this group and were described as P. sartoryi (Thom 1930). This species was placed in synonymy with P. citrinum (Pitt 1979; Pitt et al. 2000). However, Peterson (2000) suggested that $P$. sartoryi is a distinct species, based on ITS and partial 28S rDNA data. Re-analyses of the ITS regions of this species revealed a $2 \mathrm{bp}$ difference with the sequence deposited in Genbank (AF033421). Our molecular data and the extrolite profiles show that this species is conspecific with $P$. citrinum. Group 5 contains colour mutants and examination of NRRL 2145, a representative of this group, and CBS 122452, a colour mutant isolated from Thai coffee beans, showed that these two strains are $P$. citrinum. Both strains have brown coloured conidia and share partial calmodulin and ITS sequences with CBS $139.48^{\mathrm{T}}$. In contrast, both strains differ one basepair with $\mathrm{CBS} 139.48^{\mathrm{T}}$ in their partial BenA sequence. These colour mutants form a separate clade in the BenA phylogram, together with CBS 117.64, a green coloured P. citrinum, and therefore conidium colour is not an exclusive character for this subclade. Raper and Thom (1949) placed nutrient deficient mutants in group 6 and strains belonging to this group are characterized by sparse growth on Czapek's agar. The extrolite pattern of NRRL 2148 , a representative of this group, was analyzed and this strain had a P. citrinum profile (Malmstrøm et al. 2000).

Frisvad et al. (1990) noted that the type of P. implicatum is a synonym of $P$. citrinum. Pitt (1979) was unaware of the existence of the type material and designated IMI 190235 as a neotype. CBS 232.38, the type culture of $P$. implicatum, resembles $P$. citrinum in having typical $P$. citrinum colonies and conidiophores and shares identical BenA sequences with the type of P. citrinum. Therefore Frisvad et al. (1990) is followed and the neotype proposed by Pitt (1979) is rejected. Penicillium phaeojanthinellum and $P$. fellutanum were also proposed by Frisvad et al. (1990) as synonyms for P. citrinum and Pitt (1979) placed $P$. botryosum in synonomy with $P$. citrinum. The placement of $P$. phaeojanthinellum and $P$. botryosum in synonymy with $P$. citrinum is confirmed here. No type material of $P$. fellutanum could be obtained and therefore the placement of this species remains unknown.

Penicillium gorlenkoanum Baghdadi, Nov. sist. Niz. Rast., 1968: 97. 1968.

= Penicillium damascenum Baghdadi, Nov. sist. Niz. Rast., 1968: 101. 1968. 
Type: CBS $408.69^{\mathrm{NT}}$ (designated here); other cultures ex-type: FRR 511 = IMI $140339=$ VKM F-1079

Description: Colony diameter, 7 days, in mm: CYA 2631; CYA $30^{\circ} \mathrm{C} 20-30 ; \mathrm{CYA}^{\circ} 7^{\circ} \mathrm{C}$ no growth; MEA 20-27; YES 26-30; CYAS 27-33; creatine agar 13-19, weak growth and no or weak acid production.

Moderate or good sporulation on CYA with grey, dull green or dark green conidia, small clear or weak yellow coloured exudate droplets, soluble pigments absent, reverse pale yellow or crème-brown. Degree of sporulation on YES variable: weak (CBS 409.69) to strong (CBS 408.69), soluble pigment absent, grey green conidia, reverse pale yellow. Colonies on MEA grey green, velvety to floccose. No reaction with Ehrlich test.

Conidiophores from aerial hyphae, predominantly irregularly biverticillate, stipes smooth, width $2.0-2.7 \mu \mathrm{m}$; metulae terminal in whorls of $2-3,12-17 \times 2.2-3.0 \mu \mathrm{m}$; phialides ampulliform, $7.5-9.0 \times 2.0-3.0 \mu \mathrm{m}$; conidia smooth to finely rough walled, globose to subglobose, variable in size, predominantly $2.0-2.5 \mu \mathrm{m}$, smaller portion of conidia larger, 2.5-3.0 $\mu \mathrm{m}$.

Diagnostic features: No growth at $37^{\circ} \mathrm{C}$, production of chanoclavine-I.

Extrolites: Citrinin, costaclavin, chanoclavine-I (Kozlovskiĭ et al. 1981a, b), and uncharacterized extrolites, tentatively named "KUSK", "WK", "WS", "WT" and "WØ".

Distribution and ecology: Soil, Syria.

Notes: Penicillium gorlenkoanum was placed in synonymy with $P$. citrinum, while $P$. damascenum was claimed to be conspecific with P. melinii (Pitt et al. 2000). Molecular data and extrolite patterns showed that $P$. gorlenkoanum and $P$. damascenum were conspecific. Both species are described in the same publication, and the name $P$. gorlenkoanum has been chosen above $P$. damascenum. Only two strains of this species were available for examination (CBS 408.69 and CBS 409.69) and both strains did not show typical terminal metulae in whorls of $5-8$, as reported and shown in the original descriptions (Baghdadi 1968). This might be due to degeneration of these cultures during preservation. The conidial size and the original drawings of the conidiophores indicate that this species belongs to the series Citrina.

Penicillium hetheringtonii Houbraken, Frisvad and Samson, sp. nov.-MycoBank MB518292; Fig. 5.

Etymology. Named after A.C. Hetherington, who first isolated citrinin (together with $\mathrm{H}$. Raistrick).

Penicillio citrino affine, sed metullis 4-8(-12) verticillatis, revero eburneo-brunneo coloniae in agaro YES, sine pigmentis diffluentibus, solutabilibus, metabolito obscuro (PR 1-x) producenti.

Holotype: CBS $122392^{\mathrm{T}}$ is designated here as the holotype of Penicillium hetheringtonii, isolated from soil of beach, Land's end Garden, Treasure Island, Florida, USA.

Description: Colony diameter, 7 days, in mm: CYA 2632; CYA $30^{\circ} \mathrm{C}$ 26-34; $\mathrm{CYA} 37^{\circ} \mathrm{C}$ 0-2; MEA 17-23; YES 27-35; CYAS 21-31; creatine agar 13-17, poor growth on creatine agar, no acid production.

Moderate to good sporulation on CYA with dull green or dark green conidia, small hyaline exudate droplets, diffusible pigments absent, reverse colour crème-brown. Moderate to good sporulation on YES, dark green conidia, reverse orange, soluble pigments absent. Colonies on MEA dark grey green, velvety, floccose in centre. No reaction with Ehrlich test.

Conidiophores borne from surface hyphae, predominant symmetrically biverticillate, terverticillate occasionally present; stipes smooth, $2.5-3.5 \mu \mathrm{m}$ in width; metulae in whorls of $4-8(-12), 11-15 \times 2.5-3.5 \mu \mathrm{m}$; phialides ampulliform, $7.0-9.2 \times 2.0-3.0 \mu \mathrm{m}$; conidia smooth to finely roughened, globose to subglobose, $2.1-$ $2.6 \times 1.9-2.5 \mu \mathrm{m}$.

Extrolites: Citrinin, quinolactacin, two anthraquinones, a compound with a chromophore like shamixanthone ("SHAMIX") and the uncharacterized extrolite PR1-x.

Diagnostic features: Metulae in verticils of 4-8 (-12), crème-brown reverse on YES without diffusible soluble pigments, production of uncharacterized metabolite PR1-x.

Ecology and distribution: Soil; Florida, USA and Queensland, Australia.

Notes: Penicillium hetheringtonii resembles P. citrinum in having similar growth rates on agar media and orange reverse on YES, but differs from P. citrinum in having broader stipes and 4-8 closely appressed metulae. Superficially, $P$. hetheringtonii resembles $P$. paxilli, though $P$. paxilli produces paxilline while $P$. hetheringtonii does not produce this compound. Penicillium hetheringtonii infrequently produces rami and might resemble $P$. brevicompactum (see Fig. 5h). Isolates of $P$. brevicompactum consistently produce rami which are more appressed, do not or grow restrictedly at $30^{\circ} \mathrm{C}$ and produce the extrolites brevianamide A, mycophenolic acid, pebrolides and Raistrick phenols (Samson and Frisvad 2004).

Penicillium sizovae Baghdadi, Nov. sist. Niz. Rast., 1968: 103.1968.

Type: CBS $413.69^{\mathrm{NT}}$; other cultures ex-type are FRR $518=$ IMI $140344=$ VKM F-1073

Description: Colony diameter, 7 days, in mm: CYA 28 39; $\mathrm{CYA} 30^{\circ} \mathrm{C} 28-34$; $^{\mathrm{CYA}} 37^{\circ} \mathrm{C}$ 0-4; MEA 27-35; YES 40-50; CYAS 29-40; creatine agar $15-23$, poor growth, weak acid production.

Good sporulation on CYA with grey green conidia, small clear exudate droplets, soluble pigments absent, reverse pale and occasionally pale crème-brown, often with concentric sulcations. Moderate to good sporulation on 

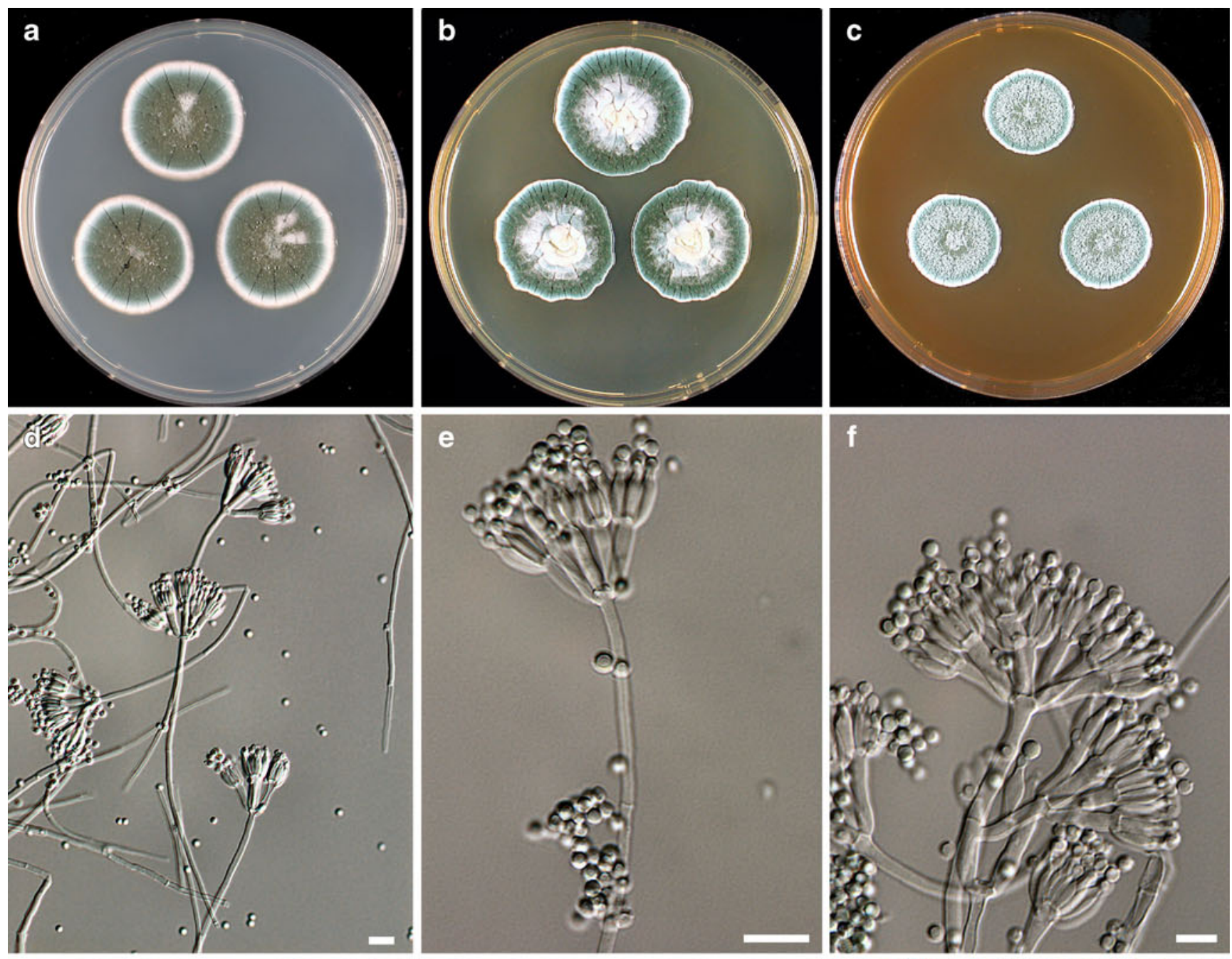

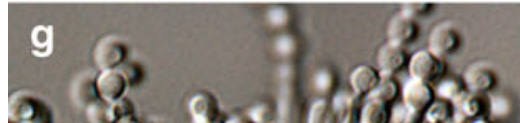

h

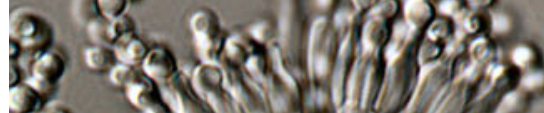

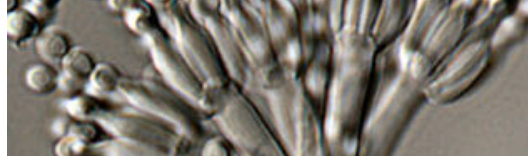

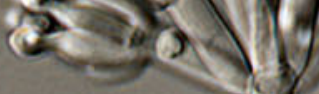
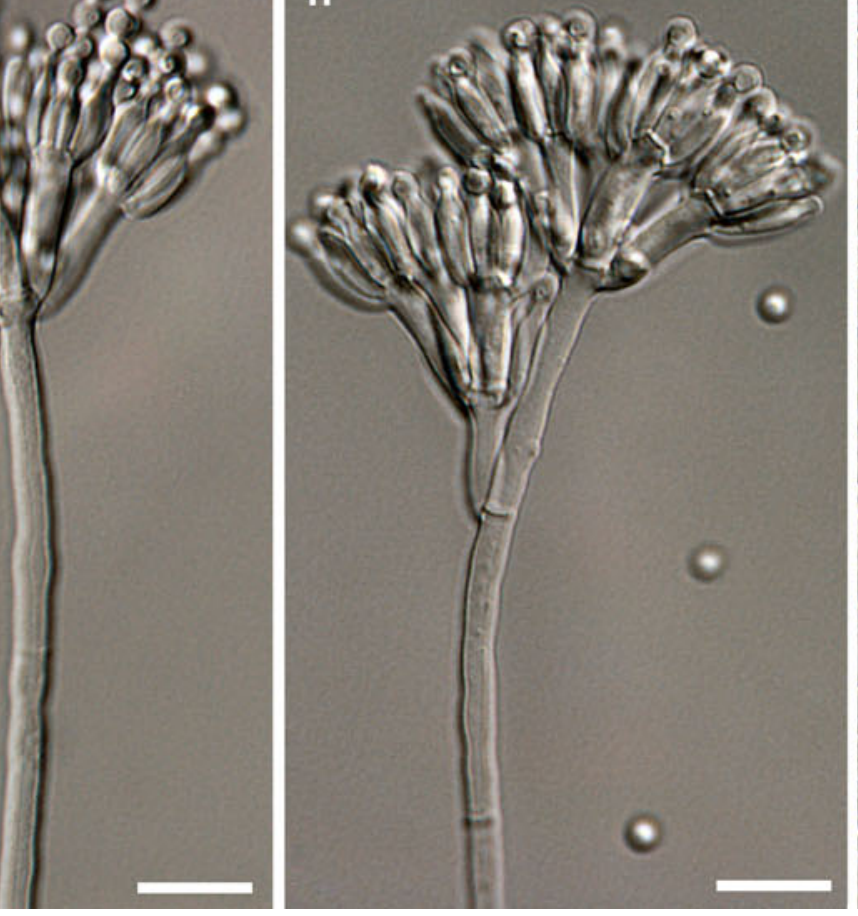

Eilles?

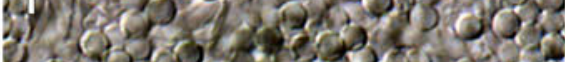

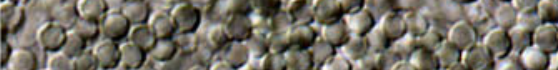

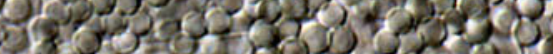

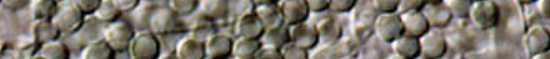

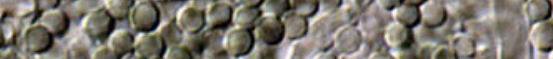

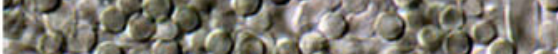

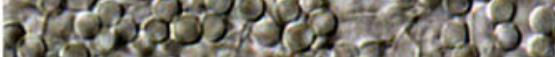

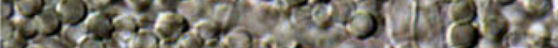

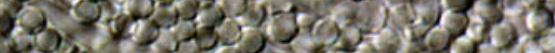
*arar a

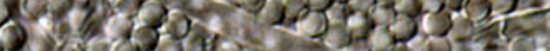
5.

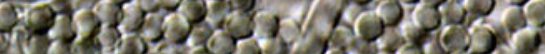

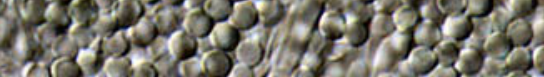

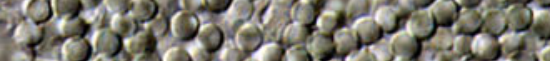

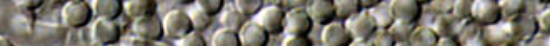

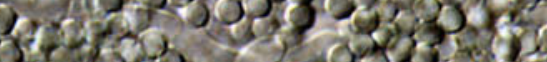

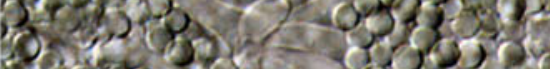
Q

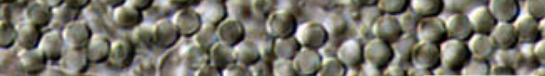


Fig. 5 Penicillium hetheringtonii. a-c Colonies grown at $25^{\circ} \mathrm{C}$ for 7 days, a CYA, b YES, c MEA; d-h conidiophores; i conidia.—scale bar $=10 \mu \mathrm{m}$

YES, dark green conidia, reverse pale or pale yellowcrème, soluble pigments absent. Colonies on MEA grey green, floccose. No reaction with Ehrlich test.

Conidiophores from aerial hyphae and mycelium mat, symmetrically biverticillate, stipes smooth, width 2.5 $3.2 \mu \mathrm{m}$; metulae in whorls of $2-5,11-16 \times 2.5-3.2 \mu \mathrm{m}$; phialides ampulliform, $7.0-9.4 \times 2.0-3.0 \mu \mathrm{m}$; conidia finely rough walled, globose to subglobose, $2.0-2.5 \mu \mathrm{m}$.

Diagnostic features: Fast growing on MEA and YES (in comparision with other related species), pale reverse on CYA, finely roughened conidia.

Extrolites: Quinolactacin, and uncharacterized extrolites, tentatively named "AFSI" and "PNUF".

Distribution and ecology: This species has been isolated from soil, margarine, sea salt, salty water in saltern, glue and Papaver somniferum in The Netherlands, Portugal, Syria, Italy, Slovenia.

Notes: Pitt (1979) placed P. sizovae in synonymy with $P$. fellutanum, but the former species was later accepted and reinstated by Pitt and Samson (1993). CBS $413.69^{\mathrm{NT}}$ is degenerated and shows both conidiophores with terminal metulae, as well as subterminal and intercalary metulae. This could explain the placement in P. fellutanum. Fresh isolates of $P$. sizovae have similar growth rates on CYA as $P$. citrinum and form terminal metulae, which indicates that this species is related to $P$. citrinum.

Penicillium steckii K.M. Zalessky, Bulletin Acad. Polonaise Sci., Math. et Nat., Sér. B: 469. 1927.

= Penicillium corylophiloides $\mathrm{S}$. Abe, J. gen. appl. Microbiol, Tokyo 2: 89. 1956. (nom. inval, Art. 36)

Type: IMI $40583^{\mathrm{NT}}$; other cultures ex-type: CBS $260.55=$ ATCC $10499=$ CECT $2268=$ DSM $1252=$ NRRL $2140=$ QM 6413 = NDRC 52B4C

Description: Colony diameter, 7 days, in mm: CYA 24 32; CYA $30^{\circ} \mathrm{C} 15-23$; $\mathrm{CYA}^{\circ} 7^{\circ} \mathrm{C}$ no growth; MEA $21-30$; YES 29-40; CYAS 26-36; creatine agar 12-18, weak to moderate growth, no or weak acid production.

Moderate or good sporulation on CYA with grey green conidia, small clear or weak yellow exudate droplets, soluble pigments absent, reverse in shades of crème (crème, pale crème, yellow-crème or brown crème). Moderate to good sporulation on YES, grey or dull green conidia, reverse light yellow, some strains yellow or light yellow with a yellow-brown center, soluble pigment absent. Colonies on MEA grey green or dull green, velvety. No reaction with Ehrlich test, with exception of CBS 122391.
Conidiophores from surface hyphae, symmetrically biverticillate, stipes smooth, width 2.2-3.0; metulae in whorls of $3-6,13-18 \times 2.5-3.3 \mu \mathrm{m}$; phialides ampulliform, $7.0-10 \times 2.2-3.0 \mu \mathrm{m}$; conidia smooth walled, broadly ellipsoidal, in some strains slightly fusiform, $2.3-3.1 \times 2.0-2.6 \mu \mathrm{m}$.

Diagnostic features: No growth at $37^{\circ} \mathrm{C}$, reverse colours on CYA in shades of crème, broadly ellipsoidal conidia.

Extrolites: Isochromantoxins (Cox et al. 1979; Malmstrøm et al. 2000), quinolactacin, tanzawaic acid E and uncharacterized extrolites tentatively named "FON", "FOS", "phoe" and "STOK".

Distribution and ecology: This species has a worldwide distribution and has been isolated in Japan, the Netherlands, Panama, Venezuela, Bermuda, Egypt, Venezuela, Indonesia and Slovenia. Penicillium steckii has been isolated from cotton fabric treated with copper naphthenate, (potting) soil, hypersaline water, blue runner fish, baled coastal grass hay, artichoke, Ascidie (tunicate, urochordata), endophyte of root of coffee plant (Posada et al. 2007).

Notes: Penicillium steckii was described by Zaleski (1927) and accepted by Raper and Thom (1949) and Ramirez (1982), but was placed by Pitt (1979) in synonymy with P. citrinum. Pitt (1979) broadened the concept of $P$. citrinum for $P$. steckii and noted that strains of this species do not produce citrinin and are not able to grow at $37^{\circ} \mathrm{C}$. This study shows that this is sufficient to raise these isolates to species level. Penicillium corylophiloides was described without a Latin diagnosis and designation of a holotype specimen (Abe 1956). After its description, this species was placed in synonymy with P. corylophilum by Smith (1963), while Pitt $(1979,2000)$ placed this species in synonymy with $P$. jensenii. Abe (1956) noted that $P$. corylophiloides formed typically elliptically formed conidia, in contrast with $P$. citrinum and $P$. steckii. However, our analysis showed that $P$. steckii also forms broadly ellipsoidal conidia. Following the phylogenetic species concept, $P$. steckii and $P$. corylophiloides are separated species; however, no differences in morphology, physiology or extrolites patterns could be observed between these species and are therefore placed in synonymy. Further work should show if these are two distinct species.

Penicillium tropicoides Houbraken, Frisvad and Samson, sp. nov.-MycoBank MB518293; Fig. 6.

Etymology: The new species is related to P. tropicum.

Eupenicillio tropico affine, sed coloniis $30^{\circ} \mathrm{C}$ tarde et $38^{\circ} \mathrm{C}$ haud crescentibus, cleistotheciis griseo-brunneis abundantibus, maturescentibus post tres menses; isochromantoxina formantur.

Holotype: CBS $122410^{\mathrm{T}}$ is designated here as the holotype of Penicillium tropicoides, isolated from soil of a rainforest, near Hua-Hin, Thailand. 

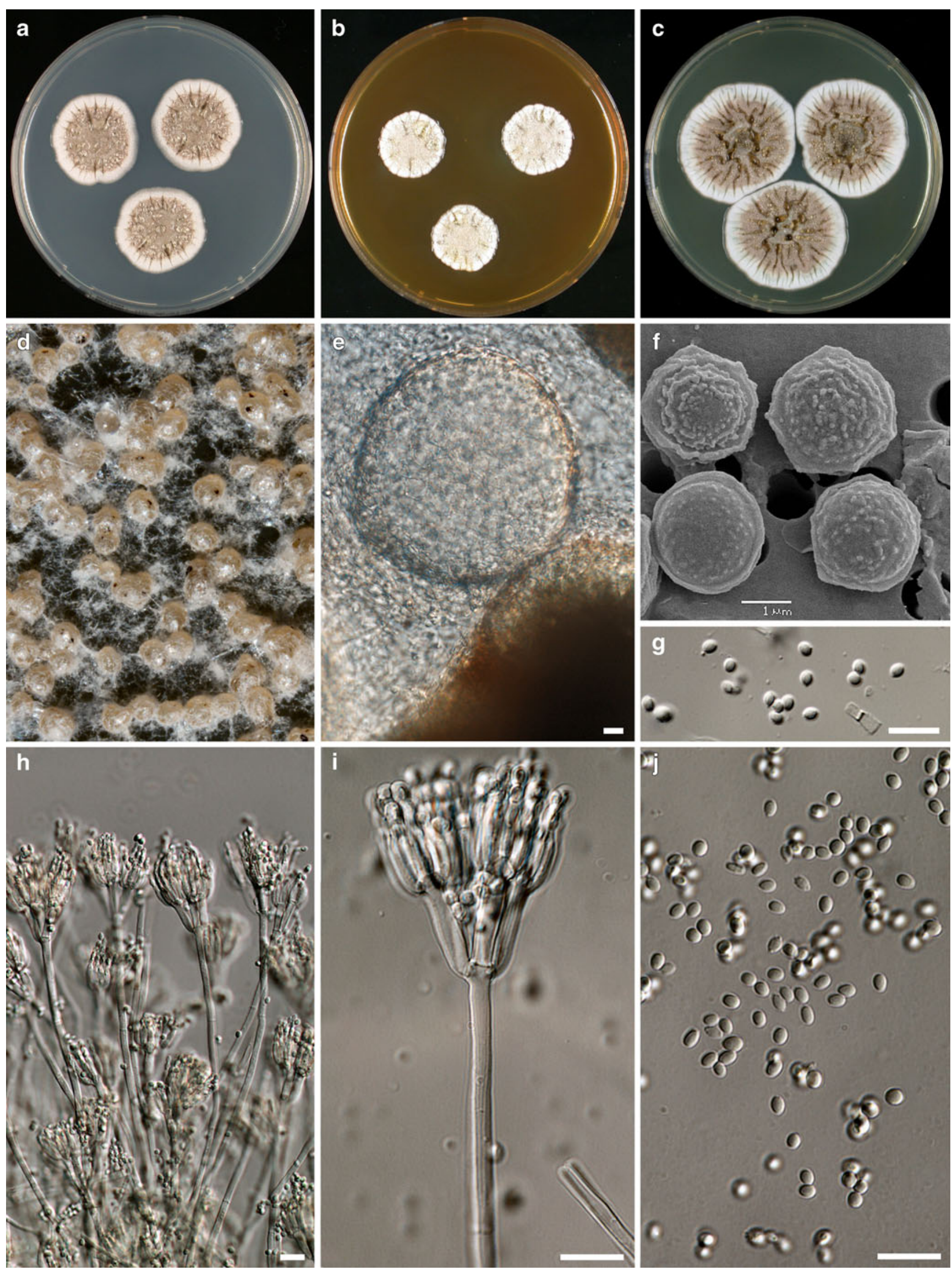
Fig. 6 Penicillium tropicoides. a-c Colonies grown at $25^{\circ} \mathrm{C}$ for 7 days, a CYA, b MEA, c YES, d-e sclerotia, f-g ascospores, h-i conidiophores, $\mathbf{j}$ conidia. - scale bar $=10 \mu \mathrm{m}$, except $\mathrm{f} .=1 \mu \mathrm{m}$

Description: Colony diameter, 7 days, in mm: CYA 2430 ; $\mathrm{CYA} 30^{\circ} \mathrm{C} 12-18$; $\mathrm{CYA} 37^{\circ} \mathrm{C}$ no growth; MEA 18-23; YES 36-43; CYAS 31-39; creatine agar 13-16, poor to moderate growth and weak acid production (under colony).

Cleistothecia abundantly produced on CYA and drab grey coloured; conidia sparsely produced, blue grey green, colonies typical with large hyaline exudate droplets, reverse on CYA crème-brown, soluble pigments absent. Weak sporulation on YES, cleistothecia abundant present and drab-grey in colour, soluble pigment absent. Colonies on MEA ascomatal, in shades of grey. No reaction with Ehrlich test.

Cleistothecia sclerotioid, 200-300 $\mu \mathrm{m}$ in diameter, ripening slowly and mature after 3 months on MEA and Oatmeal agar. Ascospores ellipsoidal, $2.4-3.2 \times 1.7-2.4 \mu \mathrm{m}$, with two narrow, closely appressed equatorial ridges, valves smooth by light microscopy, warted with anastomosing ribs by SEM. Conidiophores arising from mycelium mat, symmetrically biverticillate, stipes smooth, width 2.5-3.5; metulae in whorls of $2-5,13-17 \times 3.0-3.8 \mu \mathrm{m}$; phialides ampulliform, $8.5-10.5 \times 2.0-3.0 \mu \mathrm{m}$; conidia smooth walled, broadly ellipsoidal, $2.3-2.8 \times 1.9--2.4 \mu \mathrm{m}$.

Diagnostic features: Slow growth at $30^{\circ} \mathrm{C}$ and no growth at $37^{\circ} \mathrm{C}$, abundant production of drab-grey cleistothecia, maturing after prolonged incubation, over 3 months.

Extrolites: Isochromantoxins, several apolar indolalkaloids, and uncharacterized extrolites tentatively named "CITY", "HOLOX", "PR1-x" and "RAIMO".

Distribution and ecology: Soil in rainforest, Thailand.

Notes: Penicillium tropicoides morphologically resembles $P$. tropicum, but also has similarities with $P$. saturniforme and $P$. shearii. All these four species form lenticular ascospores with two closely appressed equatorial flanges and biverticillate conidiophores. The differences between $P$. tropicoides and $P$. tropicum are the slower maturation of the cleistothecia, slower growth rate at $30^{\circ} \mathrm{C}$ and the production of isochromantoxins by $P$. tropicoides. Penicillium shearii has a higher maximum growth temperature than $P$. tropicoides, and $P$. saturniforme has mostly smooth walled ascospores (Wang and Zhuang 2009; Stolk and Samson 1983).

Penicillium tropicoides and P. tropicum form ascospores, and in accordance with the "International Code of Botanical Nomenclature", the genus name Eupenicillium should be used. However, as shown in the phylograms (Figs. 1, 2, 3), these species are a homogeneous monophyletic group with other Penicillia. The assignment of the Penicillia to Eupenicillium (and Carpenteles) was rejected by Thom (1930) and Raper and Thom (1949). They adopted a classification with the emphasis on the Penicillium stage and treated all species, including the teleomorphic genera, as members of this genus. Using this approach and applying the concept of one name for one fungus (Reynolds and Taylor 1991), we have chosen to describe these two species under its anamorphic name.

Penicillium tropicum Houbraken, Frisvad and Samson, comb. nov.-MycoBank MB518294.

= Eupenicillium tropicum Tuthill and Frisvad, Mycological Progress 3(1): 14. 2004.

Type: SC42-1; other cultures ex-type: CBS $112584=$ IBT 24580 .

Description: Colony diameter, 7 days, in mm: CYA 24 30; $\mathrm{CYA} 30^{\circ} \mathrm{C} 20-30$; $\mathrm{CYA} 37^{\circ} \mathrm{C}$ no growth; MEA $23-27$; YES 33-37; CYAS 29-33; creatine agar 16-20, poor growth and weak acid production.

Colony appearance similar to $P$. tropicoides. Cleistothecia abundantly produced on CYA, orange-tan, becoming in warm shades of grey (brownish-grey) in age, conidia sparsely produced, blue grey green, exudate copious, large and hyaline, soluble pigments absent, reverse crème coloured. Weak sporulation on YES, cleistothecia abundantly produced deep dull grey in colour, soluble pigment absent. Colonies on MEA ascomatal, in shades of grey. No reaction with Ehrlich test.

Cleistothecia sclerotioid, 200-300 $\mu \mathrm{m}$ in diameter, ripening within 3-6 weeks on MEA and Oatmeal agar. Ascospores ellipsoidal, $2.5-3 \times 2-2.5 \mu \mathrm{m}$, with two narrow, closely appressed equatorial flanges and slightly roughened valves. Conidiophores arising from mycelium mat, symmetrically biverticillate, stipes smooth, width $2.5-3.3 \mu \mathrm{m}$; metulae in whorls of $2-5(-8), 12-16 \times 2.5-3.5 \mu \mathrm{m}$; phialides ampulliform, $8.0-10.5 \times 2.0-3.0 \mu \mathrm{m}$; conidia smooth walled, broadly ellipsoidal, $2.3-3.0 \times 2.0-2.5 \mu \mathrm{m}$.

Diagnostic features: No growth at $37^{\circ} \mathrm{C}$, abundant production of cleistothecia in warm shade of grey (brownish grey), maturing within 2-5 weeks.

Extrolites: Several apolar indol-alkaloids and the uncharacterized extrolites tentatively named "CITY", "EMON", "HOLOX" and "RAIMO" (Tuthill and Frisvad 2004).

Distribution and ecology: Penicillium tropicum has been isolated from (sub)tropical soils (e.g. India, Costa Rica, Ecuador and Galapagos Islands).

Notes: See P. tropicoides.

\section{Discussion}

Extrolite analyses showed that all species have a unique profile of metabolites (see Table 3). In general, the extrolite profiles, phenotypes and phylogeny were congruent. The only discrepancy is that $P$. steckii and $P$. corylophiloides have identical extrolite profiles, while these two species are 
phylogenetically distinct. The most well known mycotoxin produced in this group of species is citrinin. This study shows that this extrolite is produced by $P$. citrinum, $P$. gorlenkoanum and $P$. hetheringtonii and not by $P$. steckii, even though citrinin production is claimed by Jabbar and Rahim (1962). Citrinin appears to be a commonly occurring extrolite in the Citrina series and it is also produced by, for example, the closely related species $P$. chrzaszczii, $P$. westlingii, and several other related (undescribed) species (Pollock 1947; Frisvad 1989; Frisvad et al. 2004; Houbraken et al. unpublished results). Following the assumption that biosynthetic gene clusters, once acquired, for example by horizontal gene transfer, are only maintained if natural selection favours their presence (Zhang et al. 2005), it can be speculated that this biosynthetic gene cluster has been acquired once and maintained during evolution in series Citrina. In this assumption, the fungus should benefit by the production of citrinin and the biological function of this extrolite should have an important purpose. Important functions of citrinin include inhibition of bacteria (Raistrick and Smith 1941; Oxford 1942; Kiser and Zellert 1945; Michaelis and Thatcher 1945; Kavanagh 1947; Taira and Yamatodani 1947), protozoa (Hamada et al. 1952), fungi (Haraguchi et al. 1987, 1989), human cell lines (causing apoptosis) (Huang et al. 2008), cholesterol synthesis (Endo and Kuroda 1976), aldose reductase (DeRuiter et al. 1992), and UV protection (Størmer et al. 1998). Furthermore, citrinin is a strong nephrotoxin, and it is immunosuppresive, teratogenic and mutagenic and causes hemolysis of human erythrocytes (Ambrose and Deeds 1945; Lurá et al. 2004). The relative small size $(20 \mathrm{~kb})$ of this biosynthetic cluster of citrinin (Sakai et al. 2008) might also be beneficial for maintaining it in the genome during evolution. Another scenario is that horizontal gene transfer of the citrinin biosynthetic gene cluster occurred several times during the evolution of the series Citrina. The evolution of these biosynthetic genes remains unknown and more research is needed.

Besides citrinin and a series of derivates or precursors of citrinin (Clark et al. 2006; Wakana et al. 2006; Lu et al. 2008; Zhu et al. 2009), several other metabolites are also claimed to be produced by $P$. citrinum, including compactins (Endo et al. 1976), agroclavine-1 and epoxyagroclavine-1 (Kozlovskiı̌ et al. 2003a, 2005), asterric acid (Turner 1971; Turner and Aldridge 1983), cathestatins (Woo et al. 1995), citrinadin A (Tsuda et al. 2004; Mugishima et al. 2005), quinocitrinines and ergot alkaloids (Kozlovskiǐ et al. 2005), quinolactacins (Kakinuma et al. 2000; Takahashi et al. 2000; Kim et al. 2001), quinolactacide (Abe et al. 2005), tanzawaic acids (Kuramoto et al. 1997), scalusamides A-C (Tsuda et al. 2005), perinadine A (Sasaki et al. 2005), cyclocitrinols (Kozlovskiı̌ et al. 2000a; Amagata et al. 2003), ergosta-4,6,8 (14),22-tetraen-3-one (Price and Worth 1974), 2,3,4-trimethyl-5,7-dihydroxybenzofuran (Chen et al. 2002) and gibberellins (Khan et al. 2008). Of these metabolites, we have confirmed the production of citrinin and some of its derivatives, quinolactacins (= quinocitrinins), and citrinadins. Compactins have been incorrectly linked to "P. citrinum" NRRL 8082 and re-examination of this isolate showed it was a P. solitum (Frisvad and Filtenborg 1983). Clavine ergot alkaloids and citrinin have been linked to $P$. citrinum, VKM F-1079 (Kozlovskii et al. 2000b), but the strain that was used has been re-identified as $P$. gorlenkoanum. Penicillium sizovae was claimed to produce agroclavine-I and epoxyagroclavine-I and 1,1-bis(6,8-dimethyl-8,9-epoxy$5 \mathrm{a}, 10 \mathrm{e}$ )-ergoline, a dimer of epoxyagroclavine-I (Kozlovskiī et al. 1986). The P. citrinum strain VKM FW-800 was isolated from 1.8 to 3 million years old Arctic permafrost sediments. This strain produces quinolactacin (= quinocitrinin) and the ergot alkaloids agroclavine-I and epoxyagroclavine-I, which indicates that this isolate is not $P$. citrinum, and if it is not a contaminant, then it maybe a ancestor of the group of fungi treated here.

Of the investigated group of species, $P$. citrinum is most commonly occurring. This species has a worldwide distribution and has been isolated from various sources, such as soil, indoor environments and foodstuffs. In our study we found that $P$. citrinum is commonly occurring in (sub)tropical soils, and only present in low numbers in soils from temperate regions (the Netherlands, Poland, Canada), where P. westlingii and related species predominate. This is also reflected in the maximum and optimal growth temperature: P. citrinum grows up to $37^{\circ} \mathrm{C}$, while $P$. westlingii and related species have a maximum growth temperature of $30^{\circ} \mathrm{C}$. Besides commonly occurring in soil, $P$. citrinum is also reported to be an endophyte of various plants. It was the most frequently isolated species in the stem and roots of coffee plants (Posada et al. 2007), roots of Ixeris repenes (Khan et al. 2008), and from leaves of qat (Catha edulis) (Mahmoud 2000). Endophytic fungi form mutualistic interactions with their host, the relationship therefore being beneficial for both partners (Tejesvi et al. 2007; Hyde and Soytong 2008; Giordano et al. 2009). The beneficial interaction for the plant could be the production of gibberellins, which enhances stem growth, and which are claimed to be produced by $P$. citrinum (Khan et al. 2008). But also other plant growth regulators, citrinolactones $\mathrm{A}$ and sclerotinin $\mathrm{C}$, were isolated from P. citrinum (Kuramata et al. 2007) and it is reported that citrinin induces swarming motility of Paenibacillus polymyxa, a growth promoting rhizobacterium (Park et al. 2008). The production of these metabolites by $P$. citrinum in culture and/or in plants remains largely unknown and the role of this species may deserve further investigations.

Acknowledgements The authors are extremely grateful for the technical assistance of Martin Meijer and Ellen Kirstine Lyhne. Mr. Dae-Hoo Kim is thanked for the preparation of the SEM photos and prof. Uwe Braun is acknowledged for providing the Latin diagnoses. 
Open Access This article is distributed under the terms of the Creative Commons Attribution Noncommercial License which permits any noncommercial use, distribution, and reproduction in any medium, provided the original author(s) and source are credited.

\section{References}

Abe S (1956) Studies on the classification of the Penicillia. J Gen Appl Microbiol 2:1-193

Abe M, Imai T, Ishii N, Usui M, Okuda T, Oki T (2005) Quinolactacide, a new quinoline insecticide from Penicillium citrinum Thom F 1539. Biosci Biotechnol Biochem 69:12021205

Amagata T, Amagata A, Tennney K, Valeriote FA, Lobkovsky E, Clardy J, Crews P (2003) Unusual C25 steroids produced by a sponge-derived Penicillium citrinum. Org Lett 5:4393-4396

Ambrose AM, Deeds F (1945) Acute and subacute toxicity of pure citrinin. Proc Soc Exp Biol Med 59:289-291

Baghdadi VC (1968) De speciebus novis Penicilli Fr. Et Aspergilli Fr. E terries Syriae isolatis notula. Nov Syst Niz Rast 7:96114

Chen C-H, Shaw C-Y, Chen C-C, Tsai Y-C (2002) 2, 3, 4-trimethyl-5, 7-dihydroxybenzofuran, a novel antioxidant, from Penicillium citrinum F5. J Nat Prod 65:740-741

Clark BR, Capon RJ, Lacey E, Tennant S, Gill JH (2006) Citrinin revisited: from monomers and beyond. Org Biomol Chem 4:1520-1528

Cox RH, Hernandez O, Dorner JW, Cole RJ, Fennell DI (1979) A new isochroman mycotoxin isolated from Penicillium steckii. J Agric Food Chem 5:999-1001

Crous PW, Gams W, Stalpers JA, Robert V, Stegehuis G (2004) MycoBank: an online initiative to launch mycology into the 21st century. Stud Mycol 50:19-22

DeRuiter J, Jacyno JM, Davis RA, Cutler HG (1992) Studies on aldose reductase inhibitors from fungi. 1. Citrinin and related benzopyran derivatives. J Enzym Inhib Med Chem 6:210-210

Endo A, Kuroda M (1976) Citrinin, an inhibitor of cholesterol synthesis. J Antibiot 29:841-843

Endo A, Kuroda M, Tsujita Y (1976) ML-236A, ML-236B and ML236C, new inhibitors of cholesterogenesis produced by Penicillium citrinum. J Antibiot 29:1346-1348

Frisvad JC (1985) Creatine-sucrose agar, a differential medium for mycotoxin producing terverticillate Penicillium species. Lett Appl Microbiol 1:109-113

Frisvad JC (1989) The connection between the penicillia and aspergilli and mycotoxins with special emphasis on misidentified isolates. Arch Environ Contam Toxicol 18:452-467

Frisvad JC, Filtenborg O (1983) Classification of terverticillate penicillia based on profiles of mycotoxins and other secondary metabolites. Appl Environ Microbiol 46:1301-1310

Frisvad JC, Thrane U (1987) Standardized high-performance liquid chromatography of 182 mycotoxins and other fungal metabolites based on alkylphenone indices and UV-VIS spectra diode-array detection. J Chromatogr A 404:195-214

Frisvad JC, Thrane U (1993) Liquid column chromatography of mycotoxines. In: Betina V (ed) Chromatography of mycotoxines, techniques and applications. Journal of Chromatography Library. Elsevier, Amsterdam, 54:253-372

Frisvad JC, Samson RA, Stolk AC (1990) Notes on the typification of some species of Penicillium. Persoonia 14:193-202

Frisvad JC, Smedsgaard J, Larsen TO, Samson RA (2004) Mycotoxins, drugs and other extrolites produced by species in Penicillium subgenus Penicillium. Stud Mycol 49:201-241
Giordano L, Gonthier P, Varese GC, Miserere L, Nicolotti G (2009) Mycobiota inhabiting sapwood of healthy and declining Scots pine (Pinus sylvestris L.) trees in the Alps. Fungal Divers 38:69-83

Hamada Y, Fujitani H, Okamoto K, Konishi S (1952) Citrinin against protozoa. I trichomonasstatic activity in vitro. J Antibiot 5:541-544

Haraguchi H, Hashimoto K, Shibata K, Taniguchi M, Oi S (1987) Mechanisms of antifungal activity of citrinin. Biol Chem 51:1373-1378

Haraguchi H, Taniguchi M, Tanaka T, Oi S, Hashimoto K (1989) Citrinin, an electron-acceptor having antifungal activity. Agric Biol Chem 53:1741-1742

Hetherington AC, Raistrick H (1931) Studies in the biochemistry of microorganisms. XIV. On the production and chemical constitution of a new yellow colouring matter, citrinin, produced from glucose by Penicillium citrinum Thom. Phil Trans R Soc B 220:269-295

Houbraken J, Due M, Varga J, Meijer M, Frisvad JC, Samson RA (2007) Polyphasic taxonomy of Aspergillus section Usti. Stud Mycol 59:107-128

Huang Y-T, Lai C-Y, Lou S-L, Yeh J-M, Chan W-H (2008) Activation of JNK and PAK2 is essential for citrinin-induced apoptosis in a human osteoblast cell line. Environ Toxicol 24:343-356

Hyde KD, Soytong K (2008) The fungal endophyte dilemma. Fungal Divers 33:163-173

Jabbar A, Rahim A (1962) Citrinin from Pencillium steckii Zaleski. J Pharm Sci 51:595-596

Kakinuma N, Iwai H, Takahashi S, Hamano K, Yanagisawa T, Nagai K, Tanaka K, Suzuki K, Kirikae T, Nakagawa A (2000) Quinolactacins A, B and C: Novel quinoline compounds from Penicillium sp. EPF-6. I. Taxonomy, production, isolation and biological properties. J Antibiot 53:1247-1251

Kavanagh F (1947) Activities of 22 antibacterial substances against nine species of bacteria. J Bacteriol 54:761-766

Khan SA, Hamayun M, Yoon H, Kim H-Y, Suh S-J, Hwang S-K, Kim J-M, Lee I-J, Choo Y-S, Yoon U-H, Kong W-S, Lee B-M, Kim JG (2008) Plant growth promotion and Penicillium citrinum. BMC Microbiol 8:231-241

Kim WG, Song NK, Yoo ID (2001) Quinolactacins A1 and A2, new acetylcholinesterase inhibitors from Penicillium citrinum. J Antibiot 54:831-835

Kiser JS, Zellert AJS (1945) Antibiotics, other than penicillin, produced by Penicillia. Trans NY Acad Sci 7:210-219

Kozlovskii AG, Stefanmova-Avramova LR, Reshitilova TA (1981a) The effect of culture age and medium composition on the biosynthesis of alkaloids in Penicillium gorlenkoanum. Microbiologiya 50:1046-1052

Kozlovskiī AG, Stefanmova-Avramova LR, Reshitilova TA, Sakharovskii VG, Adanin VM (1981b) Clavine ergot alkaloids, metabolites of Penicillium gorlenkoanum. Prikl Biokhim Mikrobiol 17:806812

Kozlovskiı̌ AG, Vepritskaia IG, Gaiazova NB (1986) Alkaloid production in the fungus Penicillium. Prikl Biokhim Mikrobiol 22:205-210

Kozlovskiı̌ AG, Zhelifonova VP, Ozerskaya SM, Vinokurova NG, Adanin VM, Gräfe U (2000a) Cyclocitrinol, a new fungal metabolite from Penicillium citrinum. Pharmazie 55:470-471

Kozlovskiı̌ AG, Zhelifonova VP, Vinokurova NG, Ozerskaya SM (2000b) Effect of microelements on the biosynthesis of secondary metabolites by the fungus Penicillium citrinum Thom VKM F-1079. Microbiologiia 69:536-540

Kozlovskiı̌ AG, Zhelifonova VP, Adanin VM, Antipova TV, Ozeskaya SM, Kochkina GA, Gräfe U (2003a) The fungus Penicillium citrinum Thom 1910 VKM FW-800 isolated from ancient permafrost sediments as a producer of the ergot alkaloids agroclavine-1 and epoxyagroclavine-1. Microbiologiia 72:723727 
Kozlovskiĭ AG, Zhelifonova VP, Antipova TV, Adanin VM, Ozerskaya SM, Kochkina GA, Schlegel B, Dahse HM, Gollmick FA, Gräfe U (2003b) Quinocitrinines A and B, new quinoline alkaloids from Penicillium citrinum Thom 1910, a permafrost fungus. J Antibiot 56:488-491

Kozlovskiı̌ AG, Zhelifonova VP, Antipova TV (2005) Fungus Penicillium citrinum, isolated from permafrost sediments, as a producer of ergot alkaloids and new quinoline alkaloids quinocitrinines. Appl Biochem Microbiol 41:568-572

Kuramata M, Fujioka S, Shimada A, Kawano T, Kimura Y (2007) Citrinolactones $\mathrm{A}, \mathrm{B}$ and $\mathrm{C}$, and sclerotinin $\mathrm{C}$, Plant growth regulators from Penicillium citrinum. Biosci Biotechnol Biochem 71:499-503

Kuramoto M, Yamada K, Shikano M, Yazawa K, Arimoto H, Okamura T, Uemura D (1997) Tanzawaic acid A, B, C, and D: inhibitors of superoxide anion production from Penicillium citrinum. Chem Lett 9:885-886

Lu Z-Y, Lin Z-J, Wang W-L, Du L, Zhu T-J, Fang Y-C, Gu Q-Q, Zhu W-M (2008) Citrinin dimers from the halotolerant fungus Penicillium citrinum B-57. J Nat Prod 71:543-546

Lurá MC, Fuentes M, Cabagna M, González AM, Nepote A, Giugni MC, Rico M, Latorre MG (2004) Structural and ultrastructural alterations in BALB/c mice: effects of Penicillium citrinum metabolites. Mycopath 158:233-238

Mahmoud A-LE (2000) Mycotoxin-producing potential of fungi associated with qat (Catha edulis) leaves in Yemen. Folia Microbiol 45:452-456

Malmstrøm J, Christophersen C, Frisvad JC (2000) Secondary metabolites characteristic of Penicillium citrinum, Penicillium steckii and related species. Phytochem 54:301-309

Michaelis M, Thatcher FS (1945) The action of citrinin on some respiratory enzymes of Staphylococcus aureus and Escherichia coli. Arch Biochem Biophys 8:177-182

Mugishima T, Tsuda M, Kasai Y, Ishiyama H, Fukushi E, Kawabata J, Watanabe M, Akao K, Kobayashi J (2005) Absolute stereochemistry of citrinadins $\mathrm{A}$ and $\mathrm{B}$ from marine-derived fungus. J Org Chem 70:9430-9435

Oxford AE (1942) Antibacterial substances from moulds. III. Some observations on the bacteriostatic powers of the mould products citrinin and penicillic acid. Chem Ind 61:48-51

Park SY, Kim R, Ryu CM, Choi SK, Lee CH, Kim JG, Park SH (2008) Citrinin, a mycotoxin from Penicillium citrinum, plays a role in inducing motility of Paenibacillus polymyxa. FEMS Microbiol Ecol 65:229-237

Peterson SW (2000) Phylogenetic analysis of Penicillium based on ITS and LSU-rDNA sequences. In: Samson RA, Pitt JI (eds) Integration of modern taxonomic methods for classification of Penicillium and Aspergillus. Harwood, Reading, pp 163-178

Pitt JI (1979) The genus Penicillium and its teleomorphic states Eupenicillium and Talaromyces. Academic, London, pp 1-634

Pitt JI, Samson RA (1993) Species names in current use in the Trichocomaceae (Fungi, Eurotiales). In: Greuter W (ed) Names in current use in the families Trichocomaceae, Cladoniaceae, Pinaceae, and Lemnaceae, Regnum Vegetabile, Koeltz Scientific Books, Königstein, Germany, 128, pp 13-57

Pitt JI, Samson RA, Frisvad JC (2000) List of accepted species and their synonyms in the family Trichocomaceae. In: Samson RA, Pitt JI (eds) Integration of modern taxonomic methods for Penicillium and Aspergillus classification. Harwood Academic, Amsterdam, pp 9-49

Pollock AV (1947) Production of citrinin by five species of Penicillium. Nature 160:331-332

Posada F, Aime M, Peterson SW, Rehner SA, Vega F (2007) Inoculation of coffee plants with the fungal entomopathogen Beauveria bassiana (Ascomycota: Hypocreales). Mycol Res 111:748-757
Price MJ, Worth GK (1974) The occurrence of ergosta-4, 6, 8(14), 22 tetraen-3-one in several fungi. Aust J Chem 27:2505-2507

Raistrick H, Smith G (1941) Antibacterial substances from mould. I. Citrinin, a metabolic product of Penicillium citrinum Thom. Chem Ind 6:828-830

Ramirez C (1982) Manual and atlas of the Penicillia. Elsevier Biomedical, New York

Raper KB, Thom C (1949) Manual of the Penicillia. Williams \& Wilkins, Baltimore

Reynolds DR, Taylor JW (1991) Nucleic acids and nomenclature: name stability under Article 59, 171-177. In: Hawksworth DL (ed) Improving the stability of names: needs and options. Regnum Veg. 123. Koelte Scientific Books, Köningstein, Germany

Sakai K, Kinoshita H, Shimizu T, Nihira T (2008) Construction of a citrinin gene cluster expression system in heterologous Aspergillus oryzae. J Biosci Bioeng 106:466-472

Samson RA, Frisvad JC (2004) Penicillium subgenus Penicillium: new taxonomic schemes and mycotoxins and other extrolites. Stud Mycol 49:1-266

Samson RA, Hoekstra ES, Frisvad JC (2004) Introduction to foodand airborne fungi, 7 th edn. Centraalbureau voor Schimmelcultures, Utrecht

Samson RA, Houbraken J, Varga J, Frisvad JC (2009) Polyphasic taxonomy of the heat resistant ascomycete genus Byssochlamys and its Paecilomyces anamorphs. Persoonia 22:14-27

Sasaki M, Tsuda M, Sekiguchi M, Mikami Y, Kobayashi J (2005) Perinadine A, a novel tetracyclic alkaloid from marine-derived fungus Penicillium citrinum. Org Lett 7:4261-4264

Smedsgaard J (1997) Micro-scale extraction procedure for standardized screening of fungal metabolite production in cultures. J Chromatogr A 760:264-270

Smith G (1963) Some new species of Penicillium, and some observations on the taxonomy of the genus. Trans Br Mycol Soc 46:331-337

Stolk AC, Samson RA (1983) The ascomycete genus Eupenicillium and related Penicillium anamorphs. Stud Mycol 23:1-149

Størmer FC, Sandven P, Huitfeldt HS, Eduard W, Skogstad A (1998) Does the mycotoxin citrinin function as a sun protectant in conidia from Penicillium verrucosum. Mycopathologia 142:43-47

Taira T, Yamatodani S (1947) Biochemistry of Penicillium group. II. Determination of citrinin. J Penicillin 1:275

Takahashi S, Kakinuma N, Iwai H, Yanagisawa T, Nagai K, Suzuki K, Tokunaga T, Nakagawa A (2000) Quinolactacins A, B and C: novel quinoline compounds from Penicillium sp. EPF-6. II. Physico-chemical properties and structure elucidation. J Antibiot 53:1252-1256

Tejesvi MV, Kini KR, Prakash HS, Subbiah V, Shetty HS (2007) Genetic diversity and antifungal activity of species of Pestalotiopsis isolated as endophytes from medicinal plants. Fungal Divers 24:37-54

Thom C (1910) Cultural studies of species of Penicillium. US Dept Arg Bur Anim Ind Bul 118:1-109

Thom C (1930) The Penicillia. Williams \& Wilkins, Baltimore

Tsuda M, Kasai Y, Komatsu K, Sone T, Tanaka M, Mikami Y, Kobayashi J (2004) Citrinadin A, a novel pentacyclic alkaloid from marine-derived fungus Penicillium citrinum. Org Lett 6:3087-3089

Tsuda M, Sasaki M, Mugishima T, Komatsu K, Sone T, Tanaka M, Mikami Y, Kobayashi J (2005) Scalusamides A-C, new pyrrolidine alkaloids from the marine-derived fungus Penicillium citrinum. J Nat Prod 68:273-276

Turner WB (1971) Fungal metabolites. Academic, London

Turner WB, Aldridge DC (1983) Fungal metabolites II. Academic, London

Tuthill DE, Frisvad JC (2004) A new species from tropical soils, Eupenicillium tropicum. Mycol Prog 3:13-18 
Wakana D, Hosoe T, Itabashi T, Okada K, de Campos-Takaki GM, Yaguchi T, Fukushima K, Kawai K (2006) New citrinin derivatives isolated from Penicillium citrinum. J Med Chem 60:279-284

Wang L, Zhuang W-Y (2009) Eupenicillium saturniforme, a new species discovered from Northeast China. Mycopathologia 167:297-305

Woo J-T, Ono H, Tsuji T (1995) Cathestatins, new cysteine protease inhibitors produced by Penicillium citrinum. Biosci Biotechnol Biochem 59:350-352
Zaleski KM (1927) Über die in Polen gefundenen Arten der Gruppe Penicillium Link. I, II und III Teil. Bull Acad Polon Sci Lett, Classe Sci Math et Nat, Sér B: Sci Nat: 417-563, pls 36-44 (printed in 1928)

Zhang Y, Wilkinson H, Keller N, Tsitsigiannis D, An Z (2005) Secondary metabolite gene clusters. In: An Z (ed) Handbook of industrial mycology. Dekker, New York, pp 355-386

Zhu TJ, Du L, Hao PF, Lin AJ, Gu QQ (2009) Citrinal A, a novel tricyclic derivative of citrinin from the algicolous fungus Penicillium sp. i-1-1. Chin Chem Lett 20:917-920 